\title{
A Review of Digital Skills of Malaysian English Language Teachers
}

\author{
https://doi.org/10.3991/ijet.v14i02.8732 \\ Mohd Zulhilmi Che Had( ${ }^{\bowtie)}$, Radzuwan Ab Rashid \\ Universiti Sultan Zainal Abidin (UniSZA), Terenganu, Malaysia \\ mohd.zulhilmi8689@gmail.com
}

\begin{abstract}
This paper reviews the use of digital skills among Malaysian school teachers in teaching English. It starts by tracking the scenario of digital natives in the country. Next, it reviews the government policies related to the integration of ICT in education especially in English language education as the government has invested a large amount of money to implement the plan. This is followed by the discussion on teachers' digital skills in conducting English language classes. It reveals that the barriers in ICT integration are insufficient system support and teachers' reluctance to adopt the integration in English language lesson. This article also reviews the courses of continuous professional development among language teachers, which focus on the pedagogy of $\mathrm{e}$ learning. It concludes the ICT integration in English language lessons is vital and the teachers have to equip themselves with adequate digitals skills to meet the current expectations in English language learning.
\end{abstract}

Keywords-Digital skills, English language teaching, Malaysia, continuous professional development, virtual learning environment.

\section{Introduction}

The development of digital world is generating vast new opportunities for exchange and cooperation in many industries. Keeping up with the new technology to accommodate the learning needs among the new generation of digital natives is crucial among teachers [13]. Education sector needs to accommodate the needs of the younger generations who were born in an era which is different from the era of the teachers [26],[30]. In this epoch, the students are exposed to advanced information technology without borders at their fingertips. They have smartphones and mobile data, which allow them to have access to countless authentic materials on the internet.

However, there are gaps between teachers and students as some teachers still stick to conventional methods to conduct lessons especially in language learning classes. Some of the teachers label themselves as digital immigrants as opposed to digital natives [6]. It is a lacking factor in language acquisition as the learners are not fully aware of their potential of exploring virtual learning environment to learn English because they are not well exposed to this by their language instructors. In the meantime, the Ministry of Education has allocated and spent a large amount of money in order to 
equip the government schools with ICT facilities as well as ICT tools and equipment for teachers [17]. In addition, structured programmes are organised for teachers to train them on the use ICT to enhance their teaching and learning sessions [27]. However, there are debates on the effectiveness of the programmes organized as most of them are in form of cascading courses as a mean to cut down the expenses [10] [29].

This review is carried out to explore to what extent English language teachers utilise their digital skills to encourage virtual learning environment. Continuous professional development to provide e-teaching courses to English language teachers is highly suggested to equip them with the current digital literacy to be parallel with the upcoming transformation in education.

\section{Digital Natives versus Digital Immigrants in Malaysia}

'Digital Natives' is also referred to as Net Generation in previous studies [8], [25]. Malaysia is ranked at 63 in ICT development index in 2017 by International Telecommunication Union (ITU). Malaysia stood out as having the fourth-highest proportion of digital natives in the world, despite ranking much lower globally in ICT development [15]. The internet penetration in Malaysia is considered to be at high level as reported to be $76.6 \%$ in 2016 by ITU. Users have connection to internet, which allows them to have access to tones of authentic materials for learning any language. The digital natives develop sophisticated digital competencies as well as learning preferences for which the conventional education approach is lacking [2].

Teachers should be an agent of change to successfully face the challenges in industrial revolution. The privileges of having been exposed to technology earlier among digital natives are denied if the teachers pull this generation back to their era of learning the language. It will be a waste if their privilege of being digital natives is not treated accordingly by language teachers. There are recommendations that digital natives need to be taught in a fundamentally different way. The digital natives think differently due to their early acquaintance with technology and have become acquainted to be using technology to solve the repetitive tasks that form the basis of traditional learning [6].

\section{Government Policy Related to ICT Integration in Education}

In this paper, the reforms of ICT integration in education will be reviewed, as it is a tool, which brings changes in English language learning. Principally, the Ministry of Education (MoE) has introduced four major national education reforms in response to nationwide tensions over English language performance issues. The first initiative taken is the Integrated English Language Syllabus for Primary schools or knows as KBSR, which employed the Communicative Language Teaching (CLT) approach in 1982. It emphasizes on learning language for communicative purposes and not for grammatical knowledge. Learner centeredness and contextualized use was the fundamental principles in CLT [7]. By early 1990s, the effects of this reform tapered out when 
differing results were reported in terms of teaching the communicative way besides the mismatch between syllabus objectives and CLT principles with actual practices [19].

The Smart School initiative is adopted to encourage greater use of ICT in 1997. The 'smart' way of teaching Mathematics, Science, Malay language and English is implemented in 1999, however, was inundated due to hardware and software issues [22]. The major reasons that caused teachers not to aggressively adopt and integrate ICT in their teaching are limited computer literacy, technical malfunctions, time factor, lack of instructional design which resulting in irrelevant content, insufficient hardware and ICT infrastructure [22]. Then, it was substituted by cluster schools when the Smart School initiative failed in achieving the structured goals [25]. Cluster school is a brand name assigned to schools identified to be excellent in its cluster in terms of overall school management excellences and outstanding students' achievement. Through this initiative, teachers have been sent for courses and trainings in order to equip them with the necessary ICT skills. As the teachers received trainings according to their teaching options, it is hoped that these teachers will integrate ICT into their teaching session with the students.

A comprehensive review of the national education system is subsequently conducted in 2011, which resulted to the development of Malaysia Education Blueprint, 20132025 (MEB) which was launched in 2012. The implementation of MEB brought about the third education reform for primary education with the introduction of Primary School Standards-Based Curriculum or KSSR in 2013. Through this, English literacy in the Literacy and Numeracy Screening (LINUS) programme was introduced. The LINUS programme underlined the imperative to ensure $100 \%$ of primary school children are literate in Bahasa Melayu and not less than $90 \%$ in English language by the end of year three at primary school [17]. However, there are shortcomings of this programme as it is claimed that no additional courses and trainings are provided before the program was started [9].

In the MEB, the government of Malaysia strives to harness ICT in enhancing the effectiveness of the educational presentation quality in schools. In this regard, a huge capital investment was rolled out by the MOE in the last two decades to provide ICT equipment and tools at schools all over the country. Since 1999 to 2010, the government had invested approximately 6 billion MYR for ICT, which includes the introduction and implementation of FROG Virtual Learning Environment in education [17]. This huge investment should bring a very positive result in term of students' performances and achievement in academic and non-academic areas.

The fourth reformation is the English Language Education roadmap for Malaysia 2015-2025 [1]. In the recent education reform, MBMMBI is introduced to deliver significant improvements in the English proficiency of all students and as well as to learn from the shortcomings and implementation issues from previous programmes such as English for Teaching Mathematics and Science (ETeMS) [17]. The roadmap, which is designed progressively, associated with the MEB serves as a guide for English language curriculum developers and teachers to ensure that students achieve proficiency levels aligned to the Common European Framework of Reference (CEFR) as international benchmark standards. Materials in form of CDs were distributed to school to be used as teaching aids [4]. The materials are designed to be parallel with 
common practice of Computer-Assisted Language Learning (CALL) to help the digital natives to learn English language in recent pedagogical approach.

The following section will discuss the use of Virtual Learning Environment (VLE) as integration of ICT and English language education in Malaysia. It will reprise the effects of the education reforms as discussed earlier in relation to the shifts in medium of instruction language policy on the aspirations and development of English language teaching and learning programmes.

\section{The Use of Virtual Learning Environment to Teach English}

Frog Virtual Learning Environment (FROG VLE) is a cloud-based learning. It is designed as a web-based platform to provide support for the teachers to employ and manage lesson process online [11]. It does not only support e-learning activities but it provides a rich media environment with abundant graphics, animation, video, sound and hyperlinks too [3]. The FROG VLE provides a plethora of educational resources and cool applications for learning sessions inside and outside classrooms [24]. However, studies reveal a number of factors, which influence teacher's decision to integrate ICT in the classroom. Personal characteristics such as age, gender, educational level, educational experience, experience with the computer for educational purpose and attitude towards computers can influence the adoption of the technology [21]. There are seven barriers, which affect the integration of ICT into lessons: lack of time for the integration, lack of confidence among teachers during integration, lack of access to resources, lack of effective training and supports, age of the teachers, lack of personal access during lesson preparation and teaching experience [14].

Stepping into any classroom in the country today is almost the same as stepping in to any classroom 20 years ago [5]. Although the technology is used in every aspect of students' lives, it does not really happen in classrooms. The teachers revealed that their reluctance towards the use of ICT is a major barrier for ICT integration and utilization in the English language classrooms [20]. Some of the teachers are enthusiastic to integrate IT tools in their classroom, however during implementation stage their keenness withdraws and they fall back to their traditional mode of teaching due to the factors aforementioned. Even though the teachers are reluctant to change their mindset towards the integration of ICT in the teaching process, they should be aware of the importance of ICT to the digital natives and they should update their professional development to accommodate the needs of the industrial revolution.

\section{Continuous Professional Development}

It is important that teachers be prepared professionally in order for them to be able to do their jobs effectively. To achieve this, continuous professional development (CPD) is conducted to centrally maintain and enhance the quality of teaching and learning in schools. Professional development can be implemented through formal and informal approaches such as workshop, professional meetings and mentoring, while the informal approach can be achieved through, for example, reading professional 
publications, watching television documentaries related to any academic discipline and others [16], [27].

The Ministry of Education (MoE) has collaborated with other ministries and agencies on a number of capacity-building initiatives to empower educational leaders at all levels to adopt and adapt ICT in teacher preparation [12]. Metropolitan Ethernet Network (Metro-E) and Malaysian Grid for Learning (MyGfL) are provided for accessibility and connectivity as well as to be a platform for online CPD to the teachers. However, there are issues that arise due to teachers' reluctance to enroll and finish the online i-Think course. The teachers claim that the system is not user friendly due to congestion at the data server. The current progress of the online course is not saved and the teachers have to start the course all over again, which is a waste of time.

Due to limited annual budget allocation, there are some steps taken to lessen the expenditures by organizing cascading courses. The cascade model is a mechanism used to deliver training messages through several layers as it can produce many trained teachers quickly and economically. However, despite of its advantages, it is often criticized for its futility, because the message is often distorted and it hardly makes change at classroom level [23],[28]. This contributes to ineffectiveness of CPD among teachers to integrate ICT in English language learning. Due to many weaknesses in the design and implementation of CPD, it is therefore not surprising that there are still ongoing debates about the efficiency of CPD in Malaysia [16].

\section{Conclusion}

The system support of each educational reform in Malaysia is inadequate to provide assistance to teachers in order to adopt the new initiatives introduced. The Ministry of Education (MoE) needs to come out with a formal support system which is led by highly trained education personnel. Besides, MoE has to thoroughly discuss any new initiative with expert committee consisted of in-service teachers before it is announced to avoid critics that will eventually end it up with its abolishment. In addition, teachers should integrate ICT in their pedagogy thus sufficient trainings and courses should be given to them so that they can perform along with the students' expectations.

\section{$7 \quad$ References}

[1] Azman, H. (2016). Implementation and Challenges of English Language Education Reform in Malaysian Primary Schools. 3L: The Southeast Asian Journal of English Language Studies, 22(3), 65-78 https://doi.org/10.17576/3L-2016-2203-05

[2] Bennett, S., Maton, K. A., \& Lisa Kervin. (2008). Digital Native Debate: A Critical Review of the Evidence. British Journal of Educational Technology, 39 (5), 775-786. https://doi.org/10.1111/j.1467-8535.2007.00793.x

[3] Berns, A., Gonzalez-Pardo, A., \& Camacho, D. (2013). Game-like Language Learning in 3D Virtual Environments. Comput. Educ., 60(1), 210-220. https://doi.org/10.1016/j. compedu.2012.07.001 
[4] BTPN Kedah. (2016). MBMMBI CDs. Retrieved from http://pkgbtpnkedah.moe.gov.my/sungailayar/index.php/en/muat-turun/category/5-bahan-

[5] Cheok, M. L., Wong, S. L., Ayub, A. F., \& Mahmud, R. (2017). Teachers' Perceptions of E-Learning in Malaysian Secondary Schools. Malaysian Online Journal of Educational Tech

[6] Cindy, J. (2018). Using technology in the language classroom: So what if I'm not techsavvy?http://www.cambridge.org/elt/blog/2018/01/30/using-technology-languageclassroom/

[7] David, N. (2003). The Impact of English as a Global Language on Educational Policies and Practices in the Asia-Pacific Region. TESOL Quarterly, 37, 589-613 https://doi.org/10.23 $07 / 3588214$

[8] Egnatoff, W. J. (1999). Tapscott, D. (1998). Growing Up Digital. The Rise of the Net Generation. New York: McGraw Hill. Xii +338. ISSN 0-07-063361-4

[9] Eunice Ong, L., Fauzan Izzati, R., Nor Hafizah, A., \& Fatin Hazirah, M. M. (2015). Suitability of the Literacy and Numeracy Screening (Linus) 2.0

[10] Government of Malaysia. (2016). Pekeliling Perbendaharaan Malaysia. 3.11 Penganjuran Acara/ Majlis/ Keraian Rasmi Kerajaan/ Mesyuarat/ Persidangan/ Seminar/ Bengkel, 6.

[11] Hamzah, M., \& Yeop, M. A. (2016). Frog VLE (virtual learning) in teaching and learning: Acceptance and its implementation. Journal of Research, Policy \& Practice of Teachers

[12] Jamil, H., Razak, N. A., Raju, R., \& Mohamed, A. R. (2014). Teacher Professional Development in Malaysia: Issues and Challenges. Universiti Sains Malaysia, Malaysia.

[13] Jarque, C., Cwele, S. C., Ekholm, B., Martin, K., Varkey, S., Granryd, M., Mlambo, P. (2017). Working Group on Education: Digital skills for life and work.

[14] Jones, A. (2004). A Review of The Research Literature on Barriers to The Uptake of ICT by Teachers. Becta ICT Research.

[15] Joseph, S. (2013). Report: Malaysian youths fourth most active Internet users. Retrieved from http://www.themalaymailonline.com/malaysia/article/report

[16] Khalid, F., Joyes, G., Ellison, L., \& Karim, A. (2013). Teachers' Involvement in Communities of Practice: An Implication with Regard to the Current Approach of Teachers' Professional Development in Malaysia. Canadian Center of Science and Education, 9(16). https://doi.org/10.5539/ass.v9n16p102

[17] Ministry of Education Malaysia. (2013). Malaysia Education Blueprint 2013-2025.

[18] Ministry of Education Malaysia. (2016). Press Statement. Retrieved from https://www.moe.gov.my/index.php/my/arkib/pemberitahuan/2016/

[19] Normazidah, C. M., Lie, K. Y., \& Hazita, A. (2012). Exploring English language learning and teaching in Malaysia. GEMA OnlineTM Journal of Language Studies, 12, 35-51.

[20] Raman, K., \& Yamat, H. (2014). Barriers Teachers Face in Integrating ICT During English Lessons: A Case Study. The Malaysian Online Journal of Educational Technology, 2(3).

[21] Schiller, J. (2003). Working with ICT: Perceptions of Australian principals. Journal of Educational Administration, 41(2), 171-185. https://doi.org/10.1108/09578230310464675

[22] Selvaraj, B. (2010). English Language Teaching (ELT) Curriculum Reforms in Malaysia. Voice of Academia Vol.5 No.1 2010.

[23] Suzuki, T. (2008). The effectiveness of the cascade model for in-service teacher training in Nepal. IMSCI 2008

[24] Thah, S. S. (2014). Leveraging Virtual Learning Environment to Scale Up Quality Teaching and Learning in Malaysia. Asia Pacific Collaborative Education Journal, 10(1).

[25] Thang, S. M., Jaafar, N. M., Nambiar, R. M. K., Amir, Z., \& Wong, F. F. (2014). Are Malaysian Undergraduates "Digital Natives" in the True Sense of the Word.

[26] Tuminez, A. S. (2017). Bridging the gap through digital literacy. Retrieved from https://news.microsoft.com/en-my/2017/08/30/bridging-gap-digital-literacy/ 
[27] Rashid, R.A. (2018). Dialogic reflection for professional development through conversations on a social networking site. Reflective Practice, 19, 105-117. https://doi.org/ $\underline{10.1080 / 14623943.2017 .1379385}$

[28] Rashid, R.A., Rahman, S.B.A. \& Yunus, K. (2017). Reforms in the policy of English language teaching in Malaysia. Policy Futures in Education, 15(1), 100-112. https://doi.org/10.1177/1478210316679069

[29] Rashid, R.A. (2016). Responding to 'nurturing global collaboration and networked learning in higher education'. Research in Learning Technology, 24, 1-3. https:// doi.org/10.3402/rlt.v24.31485

[30] Rashid, R.A., \& Rahman, M.F. (2014). Social networking sites for online mentoring and creativity enhancement. International Journal of Technology Enhanced Learning, 6(1), 3445. https://doi.org/10.1504/IJTEL.2014.060024

\section{Authors}

Mohd Zulhilmi Che Had is a school teacher under the Ministry of Education. He is a postgraduate student in the Faculty of Languages and Communication at Universiti Sultan Zainal Abidin (UniSZA), Terenganu, Malaysia.

Dr. Radzuwan Ab Rashid works at Universiti Sultan Zainal Abidin, Malaysia. The university is managed under his supervision.

Article submitted 13 April 2018. Resubmitted 18 August 2018. Final acceptance 10 October 2018. Final version published as submitted by the authors. 